DOI 10.22363/2312-8631-2017-14-4-463-467

УДК $378+81-13+004$

\title{
FOSTERING AND DEVELOPMENT OF MULTICULTURALISM VIA SITUATIVE VOCABULARIES
}

\author{
O.V. Lvova \\ Moscow City University \\ Sheremet'evskaya str., 29, Moscow Russia, 127521
}

The search for ways and means of fostering and development of multiculturalism is now of great importance for the world community. Situational vocabulary was previously proposed by the author as an ICT tool for fostering and development of communicative competence in foreign language. They contain lexical structures used in specific communicative situations, as well as modern ICT tools (blogs, chats, forums, mail, etc.) to supplement already gained data and to discuss the ways and situations of use of various linguistic constructions or meanings of the words. Further study of the possibilities and ways of application of the instrument showed that students are not able to choose a relevant form for certain situations, or they lack or do not know the appropriate words and expressions, both in native and in a foreign language. In addition, the incorrect use of certain words or expressions in the situation may be regarded by representatives of other cultures as rude or disrespectful. The peculiarity of the method offered by the author is based on the idea of using situational vocabularies for gaining information and study of various linguistic and cultural aspects of the host country and other countries. In addition, the interaction in the familiar for learners ICT space motivates them and increase the effectiveness of such activities.

Key words: Situative vocabulary, ICT-technologies, multiculturalism

Today it is important not only to give the learner as much knowledge as possible but also provide his cultural, personal and cognitive development. Solving the problem of more effective studying educational-scientific and professional-business communication, scientists and methodologists more and more often emphasize the need for students of various fields to acquire knowledge of communication theory, skills in establishing and maintaining contacts in various spheres and situations of interaction. Of great importance are the following interdisciplinary skills:

1) ability to make a coherent oral statement;

2) ability to comply with orthoepic and grammatical rules;

3) ability to identify the intonation and meaningful utterance;

4) ability to observe emotional pause and contrast pronunciation;

5) ability to maintain a certain style of speech in communications and reports;

6) ability to use various means of presentation;

7) ability to express own opinion and substantiate it;

8) ability to arrange scientific-research work;

9) ability to retell the text (in details, selectively, briefly);

10) ability to debate. 
However, learners often face problems in this area due to differences in cultural and language traditions of other people or other social groups. The need to improve professional and language competence in a multicultural environment resulted in idea of developing such a methodical system of formation of speech competence, which would consider the speech model, correlated with different situations in different cultural environments and in different languages.

Previously the authors proposed the method of using thematic vocabularies (glossaries). Vocabulary is defined as a brief glossary to the textbook, the anthology; lexicon [3]. From a linguistic point of view, to this list one could add the dictionary to the individual texts in a foreign language. Then the idea was developed to formation of situative vocabularies (vocabulary for the situation). They include determinations of the subject components (definitions, communication objects) that are common to different disciplines and are located on any network resource (for example, group e-mail). This object may, for example, include a table of "Matching lexico-grammatical structures to the motives of speech activity". Such a vocabulary (Glossary) can be used by teachers and learners. It can be extended, unified and serve as a basis to perform a variety of learning tasks [1].

Inclusion of information and communication technologies in compilation of situative vocabularies opens up broad prospects for application of this tool. For example, it can serve not only as a basis to perform a variety of learning tasks in the development of communication competences but to be the object of project activities of learners (to be extended or updated and unified by them), under presence of associated forums, blogs, chat rooms, etc. Learners receive the opportunity to discuss ways and situations of use of various linguistic constructions or meanings of words and expressions not as a learning task but free, when due to various circumstances such experience was gained and they want to share or when a problem arises they want to find out ways the problem solved by others [2]. Experience in application of such vocabularies and subsequent research in this area revealed that the reason for the lack of communicative activity in relation to an event (e.g., birthday, victory in competition, etc.) or, even worse, an incorrect speech response to it, often lies not in the reluctance to express their feelings about the event but in inability to put them in appropriate form or the lack/ignorance of appropriate words and expressions. The consequence of this was compilation of situative vocabularies (in native language), including lexical structures used in specific communicative situations and, of course, located on shared network resources.

The next step was compilation of the situative vocabularies for situations mentioned above in foreign language. Work in this field revealed not only language but also cultural differences and associated with them mistakes. Very often learners not only use improper expressions for definite situations they even do not understand and know proper samples or modes because of cultural differences. Unfortunately this lack of knowledge is perceived by the interlocutors as rude hurtful mode of communication resulting in failure to communicate. To solve the problem authors suggested that compilation of situative vocabulary for a definite situation one should start with polling focus groups for which the tool is compiled. The questionnaire should contain questions revealing the peculiarities of the reflection of the situation in the culture of the focus group as completely as possible. Creating a proper questionnaire is of great role in solving the problem, and a critical role 
in the creation of the questionnaire plays a teacher. Then information from the questionnaire is compared with the cultural and linguistic situation in question. Relevant links are established. Necessary expressions selected. Depending on aims the resulting situative vocabulary can be simply distributed and used or used for educational purposes as described above.

Let us consider one very simple and frequent example. People especially just come from the Middle East countries or of similar culture are often confused addressing teachers, friends, elder people etc. At school it results in the situation when elder schoolchildren (9-13 years old) stop addressing the teacher at all and at the age of 14-17 make it in a rough (from our point of view) manner. A sample of questionnaire as a way to solve the problem is given below in Table.

How are people addressed to according to the age/status

\begin{tabular}{|l|l|l|}
\hline \multicolumn{1}{|c|}{ Age/status } & In your country/culture & In the host country/culture \\
\hline Peers & & \\
\hline Elder people - relatives & & \\
\hline Elder people - officially & & \\
\hline Officials & & \\
\hline $\begin{array}{l}\text { Strangers } \\
\text { a) of your age } \\
\text { b) men } \\
\text { c) women }\end{array}$ & & \\
\hline
\end{tabular}

Usually one column of the questionnaire is filled easily and does not need discussion. The other column is filled after thorough discussion with help of teacher. But the more learners do themselves (searching for relevant information/expressions) the better. Questionnaires can be devoted to a wide range of situations. Learners should be encouraged to offer themselves topics and questions to be included. On one hand such work will motivate and help learners to gain knowledge about the host country/culture, on the other hand it will give them possibility to tell about their native country/culture. Inclusion of classmates in work with the situative vocabularies is the next step aimed on fostering multiculturalism.

Development of situative vocabulary application methods revealed effectiveness of this tool in fostering multiculturalism among learners via work with it focused on compilation of situative vocabulary in foreign language for a certain situation followed or prefaced by detailed comparison of speech samples and modes in native language. Moreover interaction in familiar to learners ICT space will motivate them and increase the efficiency of such activities.

\section{LITERATURE}

[1] Львова О.В. Воспитательные функции педагогики в условиях информатизации лингвистического образования // Информационно-коммуникационные технологии в лингвистике, лингводидактике и межкультурной коммуникации: материалы V Юбилейной межд. научно-практ. конф. М., 2012. С. 245-254. 
[2] Львова О.В. Ситуативные вокабуляры как инструмент формирования метапредметных знаний и умений // Бюллетень лаборатории математического, естественнонаучного образования и информатизации. Рецензируемый сборник научных трудов. Воронеж: Научная книга, 2012. Том IV. C. 67-73.

[3] Яценко H.Е. Толковый словарь обществоведческих терминов: учебник для вузов. СПб.: Изд-во Лань, 1999. 528 с.

(C) Lvova O.V., 2017

Article history:

Received: 21 June, 2017

Accepted: 25 Jule, 2017

For citation:

Lvova O.V. (2017). Fostering and development of multiculturalism via situative vocabularies. $R U D N$ Journal of Informatization Education, 14 (4), 463-467. DOI 10.22363/2312-8631-2017-14-4463-467

\title{
Bio Note:
}

Lvova Olga Vladimirovna, candidate of pedagogical sciences, associate professor, associate professor for the chair of informatization of education of the Moscow city pedagogical university. Contact information: e-mail: olglvova@yandex.ru

\section{ИСПОЛЬЗОВАНИЕ СИТУАТИВНЫХ ВОКАБУЛЯРОВ ДЛЯ ФОРМИРОВАНИЯ И РАЗВИТИЯ МУЛЬТИКУЛЬТУРАЛИЗМА}

\author{
О.В. Львова \\ Московский городской педагогический университет \\ Шереметьевская ул., 29, Москва, Россия, 127521
}

Поиск путей и средств воспитания мультикультурализма является в настоящее время крайне актуальным для всего мирового сообщества. Ситуативные вокабуляры были ранее предложены автором в качестве ИКТ-инструмента для формирования и развития коммуникативных компетенций на родном и иностранном языках. Они содержат лексические конструкции, применяемые в определенных коммуникативных ситуациях, а также современные ИКТинструменты (блоги, чаты, форумы, рассылки и др.), позволяющие дополнять имеющийся материал и обсуждать способы и ситуации применения различных лингвистических конструкций или значения слов. Дальнейшее изучение возможностей и способов применения данного инструмента показало, что обучаемые не умеют выбрать релевантную форму для определенных ситуаций общения или им не хватает или они не знают соответствующих слов и выражений, как на родном, так и на иностранном языках.

Кроме того, неверное применение некоторых слов или выражений применительно к ситуации может рассматриваться представителями другой культуры как грубость или неуважение. 
Особенность методики автора состоит в идее использования ситуативных вокабуляров для получения информации и изучения различных языковых и культурных аспектов как страны нахождения, так и других стран. Кроме того, взаимодействие в привычном для обучаемых ИКТ-пространстве дополнительно мотивирует их и повысит эффективность подобной деятельности.

Ключевые слова: ситуативные вокабуляры, ИКТ-технологии, мультикультурализм

\section{REFERENCES}

[1] L'vova O.V. Vospitatel'nye funkcii pedagogiki v uslovijah informatizacii lingvisticheskogo obrazovanija [Educational functions of pedagogy under process of education Informatization]. Informacionnokommunikacionnye tehnologii v lingvistike, lingvodidaktike i mezhkul'turnoj kommunikacii [Information and communication technologies in linguistics, linguodidactics and intercultural communication]: materialy V Jubilejnoj mezhdunarodnoj nauchno-prakticheskoj konferencii. M., 2012. Pp. 245-254.

[2] L'vova O.V. Situativnye vokabuljary kak instrument formirovanija metapredmetnyh znanij $i$ umenij [Situational vocabulary as a tool to enhance interdisciplinary knowledge and skills]. Bjulleten' laboratorii matematicheskogo, estestvennonauchnogo obrazovanija i informatizacii. Recenziruemyj sbornik nauchny trudov [Bulletin of laboratory of mathematical, natural science education and information. Peer-reviewed collection of scientific papers]. Voronezh: Nauchnaja kniga, 2012. Vol. IV. Pp. 67-73.

[3] Jacenko N.E. Tolkovyj slovar' obshhestvovedcheskih terminov [Dictionary of social science terms]: uchebnik dlja vuzov. SPb.: Izd-vo Lan', 1999. 528 p.

\section{История статьи:}

Дата поступления в редакцию: 21 июня 2017

Дата принятия к печати: 25 июля 2017

\section{Для цитирования:}

Львова О.В. Использование ситуативных вокабуляров для формирования и развития мультикультурализма // Вестник Российского университета дружбы народов. Серия «Информатизация образования». 2017. T. 14. № 4. C. 463-467. DOI 10.22363/2312-8631-2017-14-4463-467

\section{Сведения об авторе:}

Львова Ольга Владимировна, кандидат педагогических наук, доцент, доцент кафедры информатизации образования Московского городского педагогического университета. Контактная информация: e-mail: yandex.ru 